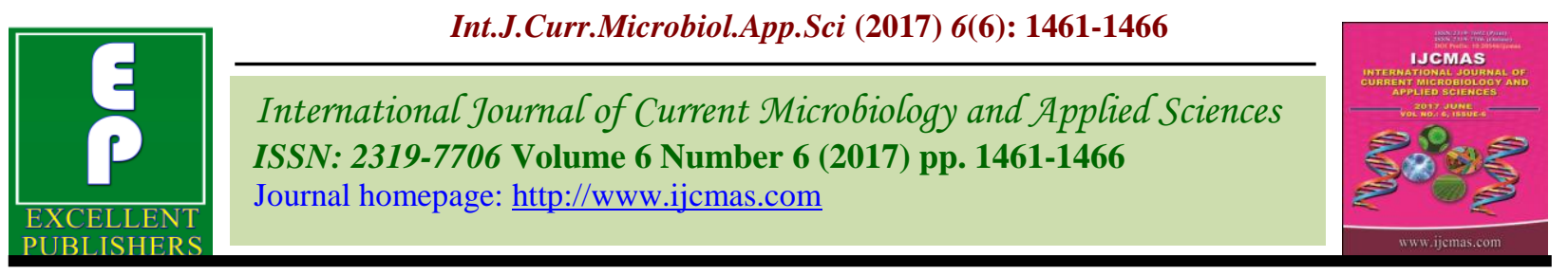

Original Research Article

https://doi.org/10.20546/ijcmas.2017.606.171

\title{
Screening of Certain Okra Genotypes against Yellow Vein Mosaic Virus Disease under Field Conditions
}

\author{
G. Srasvan Kumar ${ }^{*}$ and S.V.S. Raju \\ Department of Entomology and Agriculture Zoology, BHU, Varanasi, India \\ *Corresponding author
}

A B S T R A C T

A field experiment was carried out to screen 18 okra genotypes for YVMV

Keywords

Okra genotypes, YVMV, Per cent disease incidence and Co-efficient of infection.

Article Info

Accepted:

21 May 2017

Available Online:

10 June 2017 resistance. The per cent plant infection and the reaction of the genotypes were assessed based on the disease incidence and response value assigned by each severity grade. Among 18 genotypes during 2014-15, minimum PDI was registered in VRO-6 (10.77 \%) followed by IIVR-11 (12.50\%) and VRO-22 $(19.05 \%)$ while maximum PDI was recorded in Pusa Sawani $(72.06 \%)$ followed by EC-329357 (56.45 \%). In second year of experimentation during 2015-16 also, minimum PDI was exhibited by genotype VRO-3 $(8.73 \%)$ followed by VRO-22 $(15.66 \%)$ and maximum PDI was exhibited in Pusa Sawani $(77.15 \%)$. It was observed that during both the years VRO-6 and IIVR-11 found resistance while Pusa Sawani found highly susceptible. During 2014-15, nine genotypes were assessed as moderately resistant, four moderately susceptible and two susceptible genotypes, whereas in 2015-16, five genotypes were moderately resistant, seven genotypes were moderately susceptible and two were susceptible.

\section{Introduction}

Okra or Bhindi [Abelmoschus esculentus (L.) Moench] is an annual, herbaceous plant belonging to Malvaceae with erect growth habit. It is a bisexual plant with or without branches. Okra is native to Afro-Asian countries but also cultivated widely in India, Nigeria, Pakistan, Ghana, Egypt etc. (Akanbi et al., 2010).

In India vegetables are cultivated in an area of 9465 ' 000 ha with a production of 168506 '000 MT and productivity of 17.6 MT ha ${ }^{-1}$ during 2015-16. Among vegetables, okra (Abelmoschus esculantus (L) Moench) is one of the most important vegetable crops that fetch higher remuneration to the farmers there by elevating the socio-economic status. In India it was cultivated in an area of 504 ' 000 ha, with a production of 5794 ' 000 MT and productivity of 12.0 MT ha ${ }^{-1}$ during 2015-16 (Indian Horticulture Database $1^{\text {st }}$ estimate2015-16).

In India its fruits are cooked as vegetable, matured pods and stem have been used in paper industry where as whole plant is used as clarifier in jaggary production. The ripe seed of 'okra' are, sometimes roasted and ground as a coffee substitute, while the seed-powder has been used as substitute for the aluminum 
salts for water purification (Vaidya and Nanoti, 1989). Moreover, okra mucilage is suitable for medicinal and industrial applications (Akinyele and Temikotan, 2007).

'Okra' is fat and cholesterol free, very low in sodium, low in calories, and good source of vitamin $A$, vitamin $C$, vitamin $B 6$ and of the thiamin. Okra green fruits contain water $(88 \%)$, carbohydrate $(7.7 \%)$, protein $(2.2 \%)$, calcium $(0.09 \%)$, phosphorus $(0.04 \%)$, iron (0.0051\%), vitamin A-58 IU, vitamin B- 63 IU and vitamin c16 mg/100g (Baloch et al., 1990).

Okra crop is challenged by a various fungal, bacterial, viral and nematode diseases. Among viral diseases Yellow Vein Mosaic virus (YVMV) is the most important and devastating (Prakasha et al., 2010) gemini viruses and is transmitted by the insect pests. It was first reported on okra plants in 1924 in India and Sri Lanka.

It is transmitted by whitefly (B. tabaci) in a persistent circulative manner (Fajinmi and Fajinmi, 2010). The disease infects all the stages of crop growth with symptoms like alternate green and yellow patches, vein clearing and chlorosis of leaves.

In case of severe infection, chlorosis may result in complete yellowing of leaves and fruits will be dwarfed, malformed with yellow green appearance (Baghat et al., 2001). The yield losses in okra due to the YVMV was recorded up to 20-30 \% and may increase to $80-90 \%$ under severe infestation (Ali et al., 2005). Use of heavy doses of insecticides at frequent intervals is discouraged in vegetables due to several constraints such as health hazards, environmental pollution and short crop period. Therefore, to meet the above mentioned challenges a study was undertaken to screen certain okra genotypes for their YVMV disease resistance and to incorporate in sustainable crop production.

\section{Materials and Methods}

The experimental material consisted of 18 okra genotypes were collected from Indian Institute of Vegetable Research station, Varanasi. An experiment was laid out in Randomized Block Design with three replications during kharif 2014 and 2015 at Vegetable Research Farm, Institute of Agricultural Sciences, Banaras Hindu University. Each entry was sown at $60 \times 30$ $\mathrm{cm}$ spacing accommodating 30 plants in each plot. The standard recommended packages of practices were followed for raising a healthy crop.

In 2014 and 2015 the incidence was recorded about 60 days after sowing. The Per cent Disease Incidence (PDI) was calculated by the formula.

$\mathrm{PDI}=\frac{\text { No of infected plants }}{\text { Total No.of plants }} \times 100$

For assessing the Yellow Vein Mosaic Virus in okra genotypes, the intensity of the Yellow Vein Mosaic disease was calculated according to method suggested by Banarjee and Kallo (1987).

The Coefficient of Infection (CI) was calculated by multiplying the Per cent Disease Incidence by the response value assigned to each severity grade. Thus, the coefficient value combined the amount of infection and its severity. The severity rating was assessed visually.

\section{Results and Discussion}

YVMV incidence and co-efficient of infection during $k$ harif period 2014-15

Among 18 genotypes, none of the genotypes found free from YVMV infection. The range of per cent diseases incidence varied from 10.77 to $72.06 \%$. The genotype VRO-6 
exhibited very less (10.77) per cent diseases incidence which was at par with IIVR-11 $(12.50 \%)$ and significantly differed with remaining genotypes. The genotypes VRO22, NOKH-1002, IC-282280 and IIVR-10 showed mild per cent diseases incidence as $19.05,22.22,23.44$ and $25.60 \%$ next to above genotypes. Highest per cent diseases incidence was observed in Pusa Sawani as 72.06. The other rest of the genotypes showed intermediate range of per cent diseases incidence (26.56 to $56.45 \%$ ).

Among 18 genotypes none of genotypes found highly resistance whereas, VRO-6 and IIVR-11 found resistant to YVMV with coefficient infection of 5.38 and 6.25, respectively. Pusa Sawani was found highly susceptible to YVMV with 72.06 per cent coefficient of infection. Coefficient infection of EC-329357 and IC-111512 was found to be 56.45 and 55.56 per cent respectively and their reaction against YVMV was assessed to be susceptible. Nine genotypes Viz., IC282280, IC-117140, IC-69304, IC-288892,
NOKH-1002, IIVR-10, VRO-3, VRO-22 and HRB-55 recorded coefficient infection values between 10-19 per cent and were categorized under moderately resistance. Under moderately susceptible category, four genotypes Viz., IC-282232, 2-A, IC-111523 and IC-52310 with coefficient infection values $24.99,25.40, \quad 32.95$ and 37.50 respectively were classified (Tables 1 and 2).

\section{YVMV incidence and co-efficient infection during $k$ harif period 2015-16}

During 2015-16 experimentation also VRO-6 showed least per cent diseases incidence (8.73 $\%)$ which was significantly differed with remaining genotypes. The genotype VRO-22 exhibited 15.64 PDI which was at par with IIVR-11 (19.94\%) and IIVR-10 (20.27\%). The other genotypes viz., NOKH-1002, IC282280, HRB-55 and IC-282232 exhibited intermediate response to disease incidence recording 25.40, 28.02, 28.62 and $29.13 \%$ diseases incidence, respectively (Table 3 ).

Table.1 Scale for classifying disease reaction of okra to Yellow Vein Mosaic Virus

\begin{tabular}{|l|c|c|c|l|}
\hline \multicolumn{1}{|c|}{ YVMV Symptoms } & $\begin{array}{c}\text { Severity } \\
\text { grade }\end{array}$ & $\begin{array}{c}\text { Response } \\
\text { value }\end{array}$ & $\begin{array}{c}\text { Coefficient } \\
\text { of infection }\end{array}$ & \multicolumn{1}{|c|}{ Reaction } \\
\hline Symptoms absent & 0 & 0 & $0-4$ & $\begin{array}{l}\text { Highly } \\
\text { Resistant(HR) }\end{array}$ \\
\hline $\begin{array}{l}\text { Very mild symptoms up to } \\
\text { 25\% leaves }\end{array}$ & 1 & 0.25 & $5-9$ & Resistant (R) \\
\hline $\begin{array}{l}\text { Appearance of symptoms in } \\
\text { 26-50\% leaves }\end{array}$ & 2 & 0.50 & $10-19$ & $\begin{array}{l}\text { Moderately Resistant } \\
\text { (MR) }\end{array}$ \\
\hline $\begin{array}{l}\text { Appearance of symptoms in } \\
51-75 \% \text { leaves }\end{array}$ & 3 & 0.75 & $20-39$ & $\begin{array}{l}\text { Moderately } \\
\text { Susceptible (MS) }\end{array}$ \\
\hline $\begin{array}{l}\text { Severe disease infection } \\
\text { symptoms above 75\% leaves }\end{array}$ & 4 & 1.00 & $40-69$ & Susceptible (S) \\
\cline { 2 - 6 } & -- & -- & $70-100$ & $\begin{array}{l}\text { Highly Susceptible } \\
\text { (HS) }\end{array}$ \\
\hline
\end{tabular}


Table.2 Performance of certain okra genotypes against

Yellow Vein Mosaic Virus (YVMV) under field conditions during 2014-15

\begin{tabular}{|c|c|c|c|c|c|c|c|c|}
\hline $\begin{array}{l}\text { Tr. } \\
\text { No. }\end{array}$ & Genotype & $\begin{array}{c}* \text { Total } \\
\text { number of } \\
\text { plants } \\
\text { observed }\end{array}$ & $\begin{array}{c}* \text { Number } \\
\text { of } \\
\text { Diseased } \\
\text { Plants } \\
\end{array}$ & $\begin{array}{c}* \text { Percent } \\
\text { Disease } \\
\text { Incidence }\end{array}$ & $\begin{array}{c}\text { Severity } \\
\text { grade }\end{array}$ & R.V & CI & Reaction \\
\hline $\mathbf{T}_{1}$ & $2-A$ & 20.67 & 7.00 & $\begin{array}{c}33.87 \\
(35.53)\end{array}$ & 3 & 0.75 & 25.40 & MS \\
\hline $\mathbf{T}_{2}$ & EC-329357 & 20.67 & 11.67 & $\begin{array}{c}56.45 \\
(48.68) \\
\end{array}$ & 4 & 1.00 & 56.45 & $S$ \\
\hline $\mathbf{T}_{3}$ & IC-282280 & 21.33 & 5.00 & $\begin{array}{c}23.44 \\
(28.97) \\
\end{array}$ & 2 & 0.50 & 11.72 & MR \\
\hline $\mathbf{T}_{4}$ & IC-111512 & 21.00 & 11.67 & $\begin{array}{c}55.56 \\
(48.30)\end{array}$ & 4 & 1.00 & 55.56 & $S$ \\
\hline $\mathbf{T}_{5}$ & IC-111523 & 22.00 & 9.67 & $\begin{array}{c}43.94 \\
(41.51) \\
\end{array}$ & 3 & 0.75 & 32.95 & MS \\
\hline$T_{6}$ & IC-117140 & 20.67 & 6.67 & $\begin{array}{c}32.26 \\
(34.65) \\
\end{array}$ & 2 & 0.50 & 16.13 & MR \\
\hline $\mathbf{T}_{7}$ & IC-282232 & 23.00 & 7.67 & $\begin{array}{c}33.33 \\
(35.28)\end{array}$ & 3 & 0.75 & 24.99 & MS \\
\hline $\mathbf{T}_{8}$ & IC-52310 & 20.67 & 10.33 & $\begin{array}{c}50.00 \\
(45.09) \\
\end{array}$ & 3 & 0.75 & 37.50 & MS \\
\hline $\mathbf{T}_{9}$ & IC-69304 & 22.00 & 6.33 & $\begin{array}{c}28.79 \\
(32.39) \\
\end{array}$ & 2 & 0.50 & 14.39 & MR \\
\hline$T_{10}$ & IC-288892 & 20.67 & 6.33 & $\begin{array}{c}30.65 \\
(33.40) \\
\end{array}$ & 2 & 0.50 & 15.32 & MR \\
\hline$T_{11}$ & $\begin{array}{l}\text { NOKH- } \\
1002\end{array}$ & 21.00 & 4.67 & $\begin{array}{c}22.22 \\
(27.97)\end{array}$ & 2 & 0.50 & 11.11 & MR \\
\hline$T_{12}$ & IIVR-10 & 21.00 & 5.33 & $\begin{array}{c}25.6 \\
(30.33) \\
\end{array}$ & 2 & 0.50 & 12.80 & MR \\
\hline $\mathbf{T}_{13}$ & IIVR-11 & 21.33 & 2.67 & $\begin{array}{c}12.50 \\
(20.60) \\
\end{array}$ & 1 & 0.50 & 6.25 & $\mathrm{R}$ \\
\hline$T_{14}$ & VRO-3 & 21.33 & 5.67 & $\begin{array}{c}26.56 \\
(30.92)\end{array}$ & 2 & 0.50 & 13.28 & MR \\
\hline $\mathbf{T}_{15}$ & VRO-6 & 21.67 & 2.33 & $\begin{array}{c}10.77 \\
(19.05)\end{array}$ & 1 & 0.50 & 5.38 & $\mathrm{R}$ \\
\hline$T_{16}$ & VRO-22 & 21.00 & 4.00 & $\begin{array}{c}19.05 \\
(25.44) \\
\end{array}$ & 2 & 0.50 & 9.52 & MR \\
\hline $\mathbf{T}_{17}$ & HRB-55 & 19.33 & 5.67 & $\begin{array}{c}29.31 \\
(32.89) \\
\end{array}$ & 2 & 0.50 & 14.65 & MR \\
\hline$T_{18}$ & $\begin{array}{l}\text { Pusa } \\
\text { Sawani }\end{array}$ & 22.67 & 16.33 & $\begin{array}{c}72.06 \\
(58.21)\end{array}$ & 4 & 1.00 & 72.06 & HS \\
\hline \multicolumn{2}{|c|}{ SE(m) } & -- & -- & $(1.30)$ & -- & -- & -- & -- \\
\hline \multicolumn{2}{|c|}{ C.D. } & -- & -- & (3.72) & -- & -- & -- & -- \\
\hline
\end{tabular}

*Mean of three replications R.V. = Response Value
Figures in the parenthesis are angular transformed values $\mathrm{CI}=$ Coefficient Infection 
Table.3 Performance of certain okra genotypes against Yellow Vein Mosaic Virus (YVMV) under field conditions during 2015-16

\begin{tabular}{|c|c|c|c|c|c|c|c|c|}
\hline $\begin{array}{l}\text { Tr. } \\
\text { No }\end{array}$ & Genotype & $\begin{array}{c}* \text { Total number } \\
\text { of plants } \\
\text { observed }\end{array}$ & $\begin{array}{c}\text { *Number of } \\
\text { Diseased } \\
\text { Plants } \\
\end{array}$ & $\begin{array}{c}\text { *Percent } \\
\text { Disease } \\
\text { Incidence }\end{array}$ & $\begin{array}{c}\text { Severity } \\
\text { grade }\end{array}$ & R.V & CI & Reaction \\
\hline$T_{1}$ & 2-A & 22.33 & 8.67 & $\begin{array}{l}38.88 \\
(38.6) \\
\end{array}$ & 3 & 0.75 & 29.16 & MS \\
\hline $\mathbf{T}_{2}$ & EC-329357 & 21.67 & 13.33 & $\begin{array}{l}61.47 \\
(51.6)\end{array}$ & 4 & 1.00 & 61.47 & S \\
\hline $\mathbf{T}_{3}$ & IC-282280 & 21.33 & 6.00 & $\begin{array}{l}28.02 \\
(32.0)\end{array}$ & 2 & 0.50 & 14.01 & MR \\
\hline $\mathbf{T}_{4}$ & IC-111512 & 21.00 & 10.67 & $\begin{array}{l}50.81 \\
(45.5)\end{array}$ & 3 & 0.75 & 38.11 & MS \\
\hline $\mathbf{T}_{5}$ & IC-111523 & 22.00 & 10.00 & $\begin{array}{l}45.43 \\
(42.4)\end{array}$ & 3 & 0.75 & 34.08 & MS \\
\hline $\mathbf{T}_{6}$ & IC-117140 & 21.00 & 8.67 & $\begin{array}{l}41.38 \\
(40.0) \\
\end{array}$ & 3 & 0.75 & 31.03 & MS \\
\hline $\mathbf{T}_{7}$ & IC-282232 & 20.67 & 6.00 & $\begin{array}{l}29.13 \\
(32.6) \\
\end{array}$ & 2 & 0.50 & 14.56 & MR \\
\hline $\mathbf{T}_{8}$ & IC-52310 & 20.33 & 11.67 & $\begin{array}{l}57.30 \\
(49.2) \\
\end{array}$ & 4 & 1.00 & 57.30 & $S$ \\
\hline $\mathbf{T}_{9}$ & IC-69304 & 21.33 & 7.33 & $\begin{array}{l}34.37 \\
(35.9)\end{array}$ & 3 & 0.75 & 25.78 & MS \\
\hline $\mathbf{T}_{10}$ & IC-288892 & 21.33 & 7.67 & $\begin{array}{l}36.06 \\
(36.9)\end{array}$ & 3 & 0.75 & 27.05 & MS \\
\hline $\mathbf{T}_{11}$ & NOKH-1002 & 21.00 & 5.33 & $\begin{array}{l}25.40 \\
(30.3)\end{array}$ & 2 & 0.50 & 12.70 & MR \\
\hline$T_{12}$ & IIVR-10 & 21.33 & 4.33 & $\begin{array}{l}20.27 \\
(26.7)\end{array}$ & 2 & 0.50 & 10.14 & MR \\
\hline $\mathbf{T}_{13}$ & IIVR-11 & 21.67 & 4.33 & $\begin{array}{l}19.94 \\
(26.5)\end{array}$ & 2 & 0.50 & 9.97 & $\mathrm{R}$ \\
\hline $\mathbf{T}_{14}$ & VRO-3 & 21.00 & 7.00 & $\begin{array}{l}33.39 \\
(35.3) \\
\end{array}$ & 3 & 0.75 & 25.04 & MS \\
\hline $\mathbf{T}_{15}$ & VRO-6 & 22.33 & 2.00 & $\begin{array}{c}8.73 \\
(16.9) \\
\end{array}$ & 1 & 0.50 & 4.36 & $\mathrm{R}$ \\
\hline $\mathbf{T}_{16}$ & VRO-22 & 23.33 & 3.67 & $\begin{array}{l}15.64 \\
(23.2) \\
\end{array}$ & 1 & 0.25 & 3.91 & $\mathrm{R}$ \\
\hline $\mathbf{T}_{17}$ & HRB-55 & 22.00 & 6.33 & $\begin{array}{l}28.62 \\
(32.3)\end{array}$ & 2 & 0.50 & 14.31 & MR \\
\hline $\mathbf{T}_{18}$ & Pusa Sawani & 22.00 & 17.00 & $\begin{array}{l}77.15 \\
(61.5) \\
\end{array}$ & 4 & 1.00 & 77.15 & HS \\
\hline \multicolumn{2}{|r|}{ SE(m) } & -- & -- & 1.24 & -- & -- & -- & -- \\
\hline & C.D. & -- & -- & 3.56 & -- & -- & -- & -- \\
\hline
\end{tabular}

*Mean of three replications $\mathrm{R} . \mathrm{V}=$ Response Value
Figures in the parenthesis are angular transformed values $\mathrm{CI}=$ Coefficient Infection
Highest per cent diseases incidence observed in genotype Pusa Sawani (77.15 \%). The rest of genotypes showed significantly high range of per cent diseases incidence (33.39 to $61.47 \%$ ). The present results were in agreement with the findings of Vijaya (2004), who reported that VRO-6 showed very less PDI as $6.80 \%$ and Ahmed and Patil (2004) reported that Pusa Sawani exhibited more per cent disease incidence as $74.99 \%$. 
During 2015 kharif season no genotypes were observed to be highly resistance for their reaction against YVMV. Under resistant group, three genotypes namely VRO-6, IIVR-11 and VRO-22 were classified as they exhibited below nine per cent coefficient of infection. Five genotypes viz., IC-282280, IC-282232, NOKH1002, IIVR-10 and HRB-55 were observed to show coefficient infection of YVMV below 19 per cent and classified under moderate resistance category. However, EC-329357 and IC-52310 categorized under susceptible due to their coefficient infection ranging between 46 to 69 per cent. The Pusa Sawani was again observed to be highly susceptible to YVMV with coefficient infection of 77.15 per cent.

During both the years VRO-6 and IIVR-11 were observed to be resistant to YVMV while Pusa Sawani was highly susceptible. These results were similar with the findings of Tiwari et al., (2012) who reported and categorized that VRO-6 resistant genotype and Pusa Sawani as susceptible genotype. Similarly, Vijaya (2004) also concluded that VRO-6 was resistant to YVMV and high susceptibility of Pusa Sawani to YVMV was reported by Ahmed and Patil (2004).

\section{References}

Ahmed, Z., and Patil, M. 2004. Screening of okra varieties against okra yellow vein mosaic virus. Karnataka J. Agri. Sci., 17(3): 613-614.

Akanbi, W.B., A.O. Togun, J.A. Adeliran and E.A.O. Ilupeju. 2010. Growth dry matter and fruit yields components of okra under organic and inorganic sources of nutrients. Am. Eur. J. Sustain. Agric., 4: $1-13$.

Akinyele, B.O. and Temikotan. T. 2007. Effect of variation in soil texture on the vegetative and pod characteristics of okra (Abelmoschus esculentus (L.)Moench). Int. J. Agri. Res., 2: 165-169.

Ali, S., M.A. Khan, A. Habib, S. Rasheed and Y. Iftikhar. 2005. Management of yellow vein mosaic disease of okra through pesticide/bio-pesticide and suitable cultivars. Int. J. Agric. and Biol., 7: 1457.

Baloch, A.F., Qayyum, S.M. and Baloch, M.A. 1990. Growth and yield performance of okra (Abelmoschus esculentus L) cultivars. Gomal Univ. J. Res., 10: 191.

Fajinmi, A.A. and O.B. Fajinmi. 2010. Incidence of okra mosaic virus at different growth stages of okra plants (Abelmoschus esculentus (L.) Moench) under tropical condition. J. Gen. Mol. Virol., 2: 28-31.

Prakasha, T.L., M.S. Patil and V.I. Benagi. 2010. Survey for bhendi yellow vein mosaic disease in parts of Karnataka. Karnat. J. Agric. Sci., 23: 658-659.

Tiwari Ajay Singh, B. Singh, T.B. Sanvai, S.K. Pandey, S.D. 2012. Screening of okra varieties for resistance to yellow vein mosaic virus under field condition. Hort Flora Res. Spectrum, 1(1): 92-93.

Vaidya, M.V. and Nanoti, M.V. 1989. Bhindi Seed Powder as coagulant in removal of turbidity from water. Indian J. Environ. Health, 31(1): 43-48.

Vijaya, M. 2004. Screening of okra entries to yellow vein mosaic virus (YVMV) disease under field conditions. Orissa $J$. Horticulture, 32(1): 75-77.

\section{How to cite this article:}

Srasvan Kumar, G. and Raju, S.V.S. 2017. Screening of Certain Okra Genotypes against Yellow Vein Mosaic Virus Disease under Field Conditions. Int.J.Curr.Microbiol.App.Sci. 6(6): 1461-1466. doi: https://doi.org/10.20546/ijcmas.2017.606.171 